\title{
Effectiveness of specific types of structured physical activities in the rehabilitation of post-mastectomy women: a systematic review
}

\section{Typy treningów i aktywności fizycznej w rehabilitacji onkologicznej oraz ich skuteczność u kobiet po mastektomii: systematyczny przegląd literatury}

\author{
Anna Włoch ${ }^{1}$, Artur Bocian², Małgorzata Biskup ${ }^{1,3}$, Szymon Krupnik ${ }^{4}$ Anna Opuchlik¹, Tomasz Ridan ${ }^{5}$, \\ Marek Zak ${ }^{3}$ \\ 1Department of Rehabilitation, Holycross Cancer Center, Kielce, Poland \\ Head: Anna Opuchlik, PhD \\ ${ }^{2}$ Department of Oncological Surgery, Holycross Cancer Center, Kielce, Poland \\ Head: Jacek Haduch, MD \\ ${ }^{3}$ Faculty of Medicine and Health Sciences, The Jan Kochanowski University, Kielce, Poland \\ Head: Prof. Marianna Janion, MD, PhD \\ ${ }^{4}$ Faculty of Physical Education and Sport, University School of Physical Education, Krakow, Poland \\ Head: Prof. Jerzy Cempla, PhD \\ ${ }^{5}$ Department of Physiotherapy, University School of Physical Education, Poland \\ Head: Prof. Marek Pieniazek, PhD
}

Key words: mastectomy, physical activity, systematic review, breast cancer, strength.

Słowa kluczowe: rak piersi, aktywność fizyczna, mastektomia.

\begin{abstract}
Around $40 \%$ of post-mastectomy women meet the requirements of general guideline recommendations of 150 minutes of moderate-intensity physical activity as a sufficient minimum for adults. However, Kyu et al. disagree with this concept in their systematic review of literature on energy expenditure, claiming it to be insufficient in breast cancer prevention.

The aim of the present study is to determine which specific type of physical activity is most commonly pursued among postmastectomy women, as well as which type of exercise proves the most beneficial for those patients.

One hundred and ten original papers were identified in all 4 research databases, out of which 8 were subjected to final evaluation. The exercise programs under evaluation comprised aerobic exercise $(n=4)$, muscle strengthening exercise $(n=2)$, and mixed aerobic and muscle strengthening activities $(n=2)$. Aerobic exercises were established as the most frequently pursued type of physical activity in post-mastectomy women.

Presently, the task of credibly evaluating overall effectiveness of rehabilitation programs featuring different types of physical activities proves rather challenging, as there is still no consensus as to the actual methods of designing a set of uniformly structured evaluation tools to be applied by all investigators.
\end{abstract}

\section{Streszczenie}

Około 40\% kobiet po mastektomii podejmuje wysiłek fizyczny o umiarkowanej intensywności trwający 150 minut w tygodniu. Kyu i wsp. stwierdzają w systematycznym przeglądzie literatury dotyczącym wydatku energetycznego, że normy te nie są wystarczające do zapobiegania nowotworowi piersi.

Celem pracy była odpowiedź na pytanie, jaki typ aktywności fizycznej jest najczęściej stosowany przez kobiety po mastektomii oraz jaki typ treningu wydaje się przynosić najlepsze korzyści dla pacjentek.

Znaleziono 110 oryginalnych prac w 4 bazach naukowych. Do ostatecznej analizy włączono 8 prac naukowych. Interwencje aktywności fizycznej u kobiet po mastektomii były wykonywane w programach aerobowych $(n=4)$, siłowych $(n=2)$ oraz mieszanych, aerobowo-siłowych $(n=2)$. Treningi aerobowe są najczęściej stosowaną formą aktywności fizycznej u kobiet po zakończonym leczeniu z powodu raka piersi.

Brak spójnych narzędzi oceny efektywności programów zawierających różne typy aktywności fizycznej nie pozwala na jednoznaczne określenie, który z programów wydaje się najbardziej korzystny dla kobiet po zabiegach mastektomii. 


\section{Introduction}

Physiotherapeutical interventions in the form of physical activity contribute to an increased range of motion in the upper limbs, higher muscle strength in both the upper and lower limbs, overall aerobic endurance, and improved quality of life in the post-mastectomy patients [1]. As a rule, those components are the subject of comprehensive assessment within one year of concluding the oncological treatment management [2]. However, information on the long-term evaluation is not available.

As the long-term outcomes of interventions are not the subject of regular monitoring, this may lead to much reduced physical activity, since very few postmastectomy women conform to the recommended volume of such an activity.

In fact, over two-thirds of the post-mastectomy women do not meet the requirements for physical activity, namely 150 minutes of moderate-intensity physical activity, or 75 minutes of moderate-to-vigorous physical activity (MVPA) per week [3]. It would appear that oncological rehabilitation is very much oriented towards the short-term goal of completing the maximum achievable level of fine motor skills, especially in view of the fact that daily physical activity recommendations are not effectively followed by patients. Furthermore, as Biskup et al. noted, 1/3 of woman treated for breast cancer had a medium and high falls-risk [4].

This supposition is further corroborated by Mason et al., who demonstrated that the number of patients that conform to the established physical activity norms within 10 years of mastectomy drops by almost one third, i.e. from 34 to $21.4 \%$ [5]. This result may be considered surprising, since physical activity at the level of 10 MET-hours/week (an equivalent of five 1-hour walks at a steady pace of $4.8 \mathrm{~km} / \mathrm{h}$ ) is required, with a view to appreciably reducing the risk of a patient's premature death due to breast cancer [6].

Having said that, patients fail to conform to the WHO recommendations on the required scope of physical activity, consequently rendering them ineffective. Additionally, the recommended scope of physical activity might well be inadequate for the purpose.

One of the arguments in favor of this assertion was provided in a systematic review by Kyu et al., who showed that morbidity among persons who were exercising at submaximal heart rate levels and with an energy expenditure of $>8000$ METs/week (an equivalent of two hours of jogging five times per week) was lower by $14 \%$, than among those whose energy expenditure did exceed 600 METs/week (five 30 -min walks at a pace of $4.8 \mathrm{~km} / \mathrm{h}$ per week) [7]. Morbidity due to breast cancer in the group of subjects who often engaged in exercise at submaximal intensity was lower by $21 \%$ [6]. For comparison, radiotherapy as an adjuvant therapy reduced breast-cancer-related morbidity over the span of 10 years by $19.3-35 \%$ [8].
The purpose of their review did not consist in explaining the actual mechanism of cancer prevention aided by a pursuit of physical activity of moderate and sub-maximal intensity. Having said that, in 2015, Pedersen et al. came up with a review study mining specific data on the impact of physical activity and likely mechanisms of its effectiveness, including therapeutic management in support of cancer treatment. They highlighted the reduction of tumor growth thanks to several mechanisms, e.g. "vascularization and blood perfusion, increasing immune function, tumor metabolism" [9]. These mechanisms, further corroborated by the results described in the study by Kyu et al., seem to be an interesting starting point, with a view to pursuing further research into the matter.

The present review aimed to determine which specific type of physical activity is most commonly pursued among post-mastectomy women, as well as which specific type of structured exercise programs proves functionally the most beneficial for them.

\section{Material and methods}

\section{Search strategy}

Two investigators conducted independent searches across four databases with PubMed, EBSCO, BASE (Bielefeld Academic Search Engine) and SciELO publications released between January 2016 and June 2016. The following search terms were used: physical activity, breast cancer, randomized clinical trial, PA, RCT, physical activity regiment, strength training, endurance training, aerobic, working age.

\section{Article selection}

Articles were selected by two independent investigators. Studies whose scope overlapped were excluded. Reports regarding the studies in which randomization had not been applied, or in which selection had been quasi-random (https://en.wikipedia.org/wiki/Low-discrepancy_sequence), were also disregarded.

\section{Exclusion criteria}

All studies which reported other types of oncological events within the study group were excluded, and so were the study protocols, materials used for information purposes only, and all meta-analyses.

\section{Types of compared measurements}

The following study variables were evaluated: range of motion of the upper limbs (goniometric measurements), aerobic endurance $\left(\mathrm{VO}_{2 \text { max }}, \mathrm{VO}_{2 \text { peak }}\right.$, results of the six-minute walk test - 6MWT), strength of the upper (grip strength) and lower limbs (leg press), relative appendicular skeletal muscle mass, severity of fatigue symptoms (FAQ - Fatigue Assessment Questionnaire, SCFS - Schwartz Cancer Fatigue Scale, FSS - 
fatigue Severity Scale, MFI - Multidimensional Fatigue Inventory, FQL - Fatigue Quality List), quality of life (the EORTC QLQ-C30 questionnaire of the European Organization for Research and Treatment of Cancer), SF-36 - the short form (36) health survey (variables comprising fatigue, depression symptoms, and anxiety), anthropometric data (lean body mass, fat mass \%, body fat \%, METs, total body mass), and informationprocessing rate (trail making test).

\section{Evaluation of research quality}

After the selection of the articles, they were checked in the PEDro database to evaluate methodological restrictions. Five out of eight articles included in the systematic review were found, with a mean score of $6.2(4-8)$ points in the database.

\section{Results}

The total number of original papers found in all four research databases was 110 . The final analysis was conducted for eight papers. Physical activity interventions in women after mastectomy included programs consisting of aerobic exercise $(n=4)$, muscle strengthening exercise $(n=2)$, and mixed aerobic and muscle strengthening exercise $(n=2)$. Exercise time (20-90 minutes) varied depending on a specific type of activity. Strength training regimen significantly increased the muscle strength, ranging $12.2-50 \%$, depending on a specifically applied method of measurement, and a respective muscle group. The results for the upper limbs and torso muscles increased by $12.2 \%$ (Bench Press), strength of the knee extensors increased by approximately $17.5 \%$ (Leg Press), and appendicular skeletal muscle mass also significantly increased.

\section{Aerobic exercise}

Interventions involving aerobic exercise were performed from 6 to 12 weeks, one to three times per week, in sessions of 20-60 minutes. It was established that the results were followed up in the longterm (six months) in $16.6 \%$ of the studies on aerobic exercise. Exercise load was calculated based on $\mathrm{HR}_{\max }$ or $\mathrm{VO}_{2 \max }$ results or the Borg scale. Although higher performance in relation to the control group was generally observed in the 6MWT test $(n=2$, $p<0.01$ ), one of the studies did not report a difference in the distance covered during this test. Aerobic exercise reduced fatigue regardless of the applied research method. One study demonstrated increased QOL, while another did not corroborate these results (i.e. QOL variables comprising fatigue, depression symptoms, and anxiety, were found diminished) (Table 1).

\section{Muscle strengthening exercise}

Interventions featuring muscle strengthening exercise were performed for periods of 12-13 weeks, twice a week, in sessions lasting from 60 to $90 \mathrm{~min}$ utes. Two studies reported the long-term follow-up of the outcomes. Exercise load was calculated based on the percentage of the $1 \mathrm{RM}$ and arbitrarily selected weight.

\section{Mixed aerobic and muscle strengthening exercise}

Interventions involving mixed aerobic and muscle strengthening exercise were performed within a span of 12-18 weeks, twice a week, in 60-minute sessions. The long-term follow-up of the results lasted $4-6$ months $(n=2)$. It was demonstrated that maximal oxygen uptake $\left(\mathrm{VO}_{2 \text { max }}, \mathrm{VO}_{\text {2peak }}\right)$ increased, when compared against the control groups. No significant differences were observed regarding the quality of life, using different research tools $(n=2)$. The results achieved via mixed interventions lasted 4-6 months.

\section{Discussion}

Regular physical activity can reduce morbidity by $20-30 \%$, depending on the specific type of disease [10]. Its efficacy was confirmed in more than 25 chronic conditions [10]. Nevertheless, the dependence between the actual volume of exercises performed and the result of the intervention must be emphasized. Kyu et al. demonstrated that high-intensity exercise at the level of $8000 \mathrm{METs} /$ week reduced the risk of premature death due to breast cancer by $21 \%$ [7]. It seems interesting that a tenfold increase in exercise intensity, compared to the $600 \mathrm{METs} /$ week recommended as the normal level of physical activity and treated as the reference value in the present review, yields a 7\% decrease in morbidity. According to some authors, considerable energy expenditure expressed in the metabolic equivalent reduces morbidity by as much as $26 \%$. The results expressed in METs, raise the question as to whether this variable is suitable for the estimation of anti-inflammatory effects; however, these particular effects of moderate- and high-intensity exercise are associated with reduced morbidity due to breast cancer [11]. At least three discrepancies seem to offer persuasive rationale for the pursuit of further, in-depth studies. Firstly, 60-75 minutes of moderate-intensity physical exercise per day merely mitigates the adverse everyday effects of a sedentary lifestyle [12]. Moderate-intensity exercise thus only helps maintain overall fitness, but it fails to contribute to its further development. Secondly, very high intensity of physical exercise proposed by Kyu et al., i.e. two hours per every day of the week, does not appear to be overly effective. Finally, reporting physical activity in terms of METs in the studies focused on breast cancer, seems to be reasonable, but it fails to address the metabolic reaction and associated hormonal response, which offer vital information 


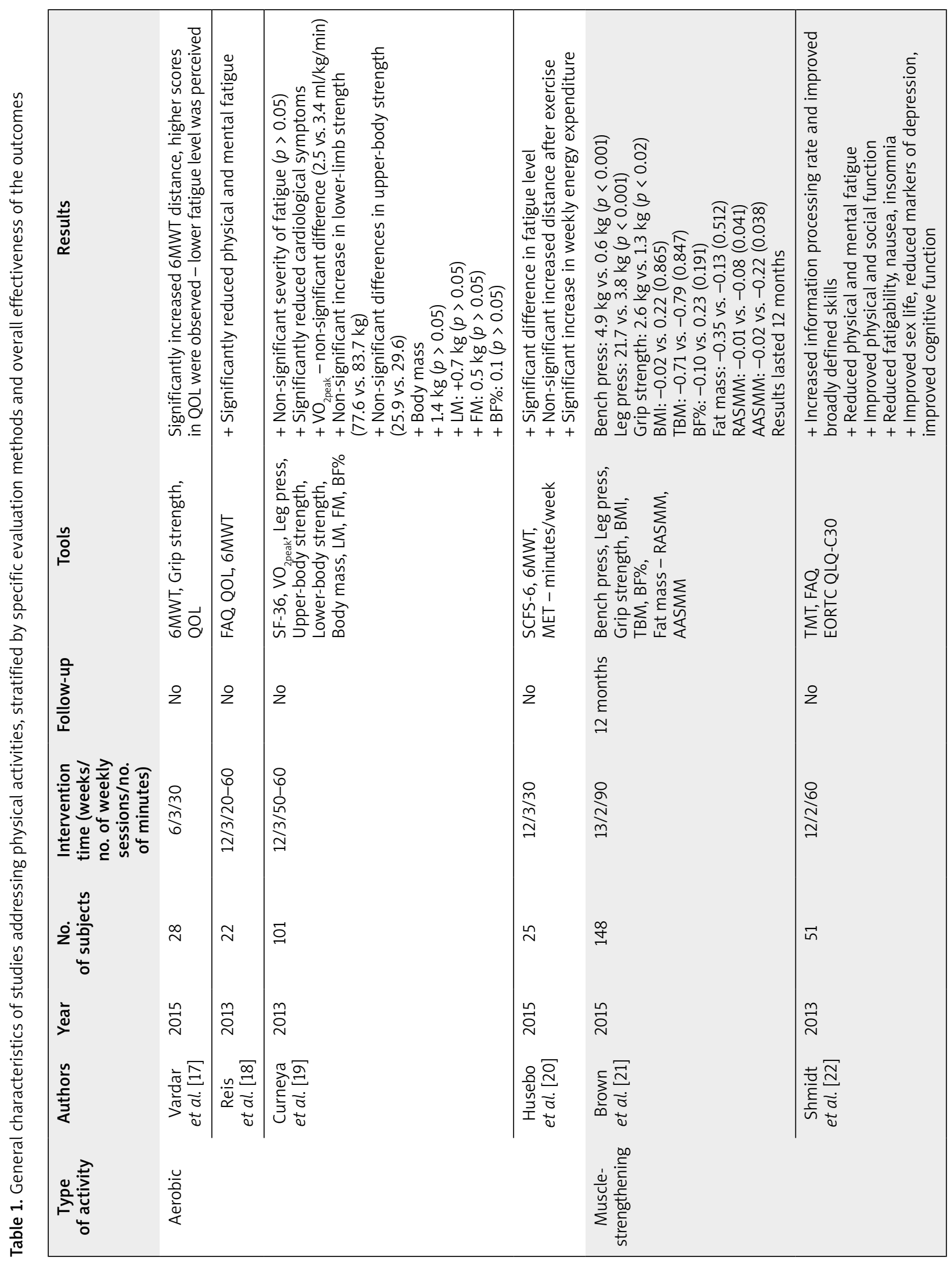




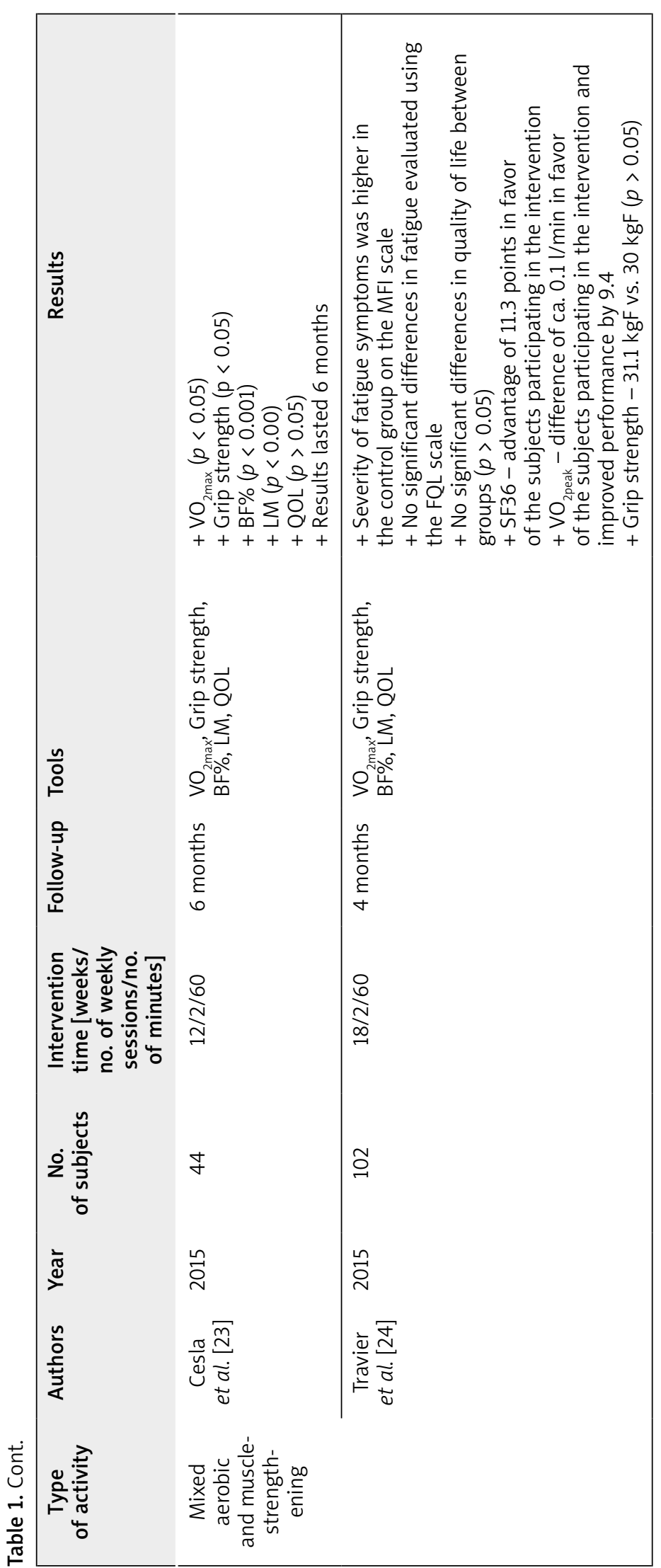

in terms of a physiological perspective. The above notwithstanding, a metabolic equivalent is recommended by the American College of Sports Medicine as a measure of physical exercise intensity in postmastectomy women [13]. Furthermore, this method is also recommended by the American Heart Association for the assessment of the intensity of physical exercise [14]. High-intensity physical activity seems to be a preventive measure of some significance in oncology at large. Kraemer et al. noted increased levels of the growth hormone, cortisol and the insulin-like growth factor 1 (IGF-1) in their literature review focused on the hormonal response after muscle strengthening exercise [15]. Furthermore, research indicates that both types of physical activity improve the patients' self-esteem, which can be explained by increased concentration of $\beta$-endorphin associated with the stimulation of hypothalamic-pituitary-adrenal (HPA) axis. This is due to the anti-inflammatory aspect (cytokines) and the balance between angiogenesis and apoptosis, in which the vascular endothelial growth factor plays a role of an inflammatory mediator. Both being overweight and/or obese affected the therapeutic outcomes in patients as bona fide contributing factors [16]. It is worth noting that only the women treated with aromatase inhibitors were able to stay truly committed to exercising throughout an entire year. The fact that as many as 30\% of oncological patients did not complete physical activity programs also bears appreciable significance [17]. The present findings should therefore be taken into account when designing specifically structured, physical rehabilitation programs.

\section{Study limitations}

The study limitations may consist in the fact that presently available research tools applied for evaluation of physical activity are both diverse and nonuniform in character. Biskup et al., in their study addressing physical activity as a contributive factor in maintaining post-mastectomy health, showed a challenging nature of the research focused on comparing academical studies evaluating overall effectiveness of post-surgical intervention outcomes, while using the diversity of research tools [25]. In the present, systematic review of literature, the research tools applied in the assessment of different components of physical activity differ significantly between studies. Lack of commonly acknowledged gold-standard procedures for measuring physical activity and its individual components in breast cancer patients, seems an obvious conclusion. Such a gold-standard should be developed, while making due allowances for patients' age stratification as well as provide a possibility of broad assessment of potential adverse events, e.g. falls-risk [27]. 


\section{Conclusions}

1. Aerobic exercise is the most common type of physical activity pursued by post-mastectomy women.

2. The diversity of research tools effectively contributes to impossibility to clearly establish which specific physical exercise models boast the largest potential for yielding the highest functional benefits in post-mastectomy women.

\section{Conflict of interest}

The authors declare no conflict of interest.

\section{References}

1. Salakari MRJ, Surakka T, Nurminen R, Pylkkänen L. Effects of rehabilitation among patients with advances cancer: a systematic review. Acta Oncol 2015; 54: 618-628.

2. Harris SR, Schmitz KH, Campbell KL, McNeely ML. Clinical practice guidelines for breast cancer rehabilitation: syntheses of guideline recommendations and qualitative appraisals. Cancer 2012; 118 (8 Suppl): 2312-2324.

3. Shmitz K, Courneya K, Matthews Ch, Demark-Wahnefried W, Galvão DA, Pinto BM, Irwin ML, Wolin KY, Segal RJ, Lucia A, Schneider CM, von Gruenigen VE, Schwartz AL; American College of Sports Medicine. American College of Sports Medicine roundtable on exercise guidelines for cancer survivors. Med Sci Sports Exerc 2010; 42: 1409-1426.

4. Biskup M, Góźdź S, Macek P, Opuchlik A, Skowronek T, Polit $€$, Żak M. Falls-risk in senior woman after radical treatment of breast cancer. Medical Studies 2017; 33: 110-116.

5. Mason C, Alfano CM, Smith AW, Wang CY, Neuhouser ML, Duggan C, Bernstein L, Baumgartner KB, Baumgartner RN, Ballard-Barbash R, McTiernan A. Long-term physical activity trends in breast cancer survivors. Cancer Epidemiol Biomarkers Prev 2013; 22: 149-160.

6. Sternfeld B, Weltzien E, Quesenberry QP Jr, Castillo AL, Kwan M, Slattery ML, Caan BJ. Physical activity and risk of recurrence and mortality in breast cancer survivors: findings from the LACE study. Cancer Epidemiol Biomarkers Prev 2009; 18: 87-95.

7. Kyu HH, Bachman VF, Alexander LT, Mumford JE, Afshin A, Estep K, Veerman JL, Delwiche K, Iannarone ML, Moyer ML, Cercy K, Vos T, Murray CJ, Forouzanfar MH. Physical activity and risk of breast cancer, colon cancer, diabetes, ischemic heart disease, and ischemic stroke events: systematic review and dose-response meta-analysis for the Global Burden of Disease Study 2013. BMJ 2016; 354: i3857.

8. Early Breast Cancer Trialists' Collaborative Group (EBCTCG), Darby S, McGale P, Correa C, Taylor C, Arriagada R, Clarke M, Cutter D, Davies C, Ewertz M, Godwin J, Gray R, Pierce L, Whelan T, Wang Y, Peto R. Effect of radiotherapy after breast-conserving surgery on 10 -year recurrence and 15-year breast cancer death: meta-analysis of individual patient data for 10,801 women in 17 randomised trials. Lancet 2011; 378: 1707-1716.

9. Pedersen BK, Saltin B. Exercise as medicine - evidence for prescribing exercise as therapy in 26 different chronic diseases. Scand J Med Sci Sports 2015; 25 Suppl 3: 1-72.

10. Warburton DE, Bredin SS. Reflections on Physical Activity and Health: What Should We Recommend? Can J Cardiol 2016; 32: 495-504.
11. Neilson HK, Farris MS, Stone CR, Vaska MM, Brenner DR, Friedenreich CM. Moderate-vigorous recreational physical activity and breast cancer risk, stratified by menopause status: a systematic review and meta-analysis. Menopause 2017; 24: 322-344.

12. Ekelund U, Steene-Johannessen J, Brown WJ, Fagerland MW, Owen N, Powell KE, Bauman A, Lee IM; Lancet Physical Activity Series 2 Executive Committee; Lancet Sedentary Behavior Working Group. Does physical activity attenuate, or even eliminate, the detrimental association of sitting time with mortality? A harmonised meta-analysis of data from more than 1 million men and women. Lancet 2016; 388: 1302-1310.

13. Kirkham AA, Campbell KL, McKenzie DC. Comparison of aerobic exercise intensity prescription methods in breast cancer. Med Sci Sports Exerc 2013; 45: 1443-1450.

14. Strath SJ, Kaminsky LA, Ainsworth BE, Ekelund U, Freedson PS, Gary RA, Richardson CR, Smith DT, Swartz AM; American Heart Association Physical Activity Committee of the Council on Lifestyle and Cardiometabolic Health and Cardiovascular, Exercise, Cardiac Rehabilitation and Prevention Committee of the Council on Clinical Cardiology, and Council. Guide to the assessment of physical activity: Clinical and research applications: a scientific statement from the American Heart Association. Circulation 2013; 128: 2259-2279.

15. Kraemer WJ, Ratamess NA. Hormonal responses and adaptations to resistance exercise and training. Sports Med 2005; 35: 339-361.

16. Eyigor S, Kanyilmaz S. Exercise in patients coping with breast cancer: An overview. World J Clin Oncol 2014; 5: 406-411.

17. Courneya KS, Segal RJ, Mackey JR, Gelmon K, Reid RD, Friedenreich CM, Ladha AB, Proulx C, Vallance JK, Lane K, Yasui Y, McKenzie DC. Effects of aerobic and resistance exercise in breast cancer patients receiving adjuvant chemotherapy: a multicenter randomized controlled trial. J Clin Oncol 2007; 25: 4396-4404.

18. Vardar Yağlı N, Şener G, Arıkan H, Sağlam M, İnal İnce D, Savcı S, Çalık Kutukcu E, Altundağ K, Kaya EB, Kutluk T, Özışı Y. Do yoga and aerobic exercise training have impact on functional capacity, fatigue, peripheral muscle strength, and quality of life in breast cancer survivors? Integr Cancer Ther 2015; 14: 125-132.

19. Reis D, Walsh ME, Young-McCaughan S, Jones T. Effects of Nia exercise in women receiving radiation therapy for breast cancer. Oncol Nurs Forum 2013; 40: E374-381.

20. Courneya KS, McKenzie DC, Mackey JR, Gelmon K, Friedenreich CM, Yasui Y, Reid RD, Cook D, Jespersen D, Proulx C, Dolan LB, Forbes CC, Wooding E, Trinh L, Segal RJ. Effects of exercise dose and type during breast cancer chemotherapy: multicenter randomized trial. J Natl Cancer Inst 2013, 105: 1821-1832.

21. Husebø AM, Karlsen B, Allan H, Søreide JA, Bru E. Factors perceived to influence exercise adherence in women with breast cancer participating in an exercise programme during adjuvant chemotherapy: a focus group study. J Clin Nurs 2015; 24: 500-510.

22. Brown JC, Schmitz KH. Weight lifting and appendicular skeletal muscle mass among breast cancer survivors: a randomized controlled trial. Breast Cancer Res Treat 2015; 151: 385-392. 
23. Schmidt T, Weisser B, Jonat W, Baumann FT, Mundhenke C. Gentle strength training in rehabilitation of breast cancer patients compared to conventional therapy. Anticancer Res 2012; 32: 3229-3233.

24. Casla S, López-Tarruella S, Jerez Y, Marquez-Rodas I, Galvão DA, Newton RU, Cubedo R, Calvo I, Sampedro J, Barakat R, Martín M. Supervised physical exercise improves VO2max, quality of life, and health in early stage breast cancer patients: a randomized controlled trial. Breast Cancer Res Treat 2015; 153: 371-382.

25. Travier N, Velthuis MJ, Steins Bisschop CN, van den Buijs B, Monninkhof EM, Backx F, Los M, Erdkamp F, Bloemendal HJ, Rodenhuis C, de Roos MA, Verhaar M, ten Bokkel Huinink D, van der Wall E, Peeters PH, May AM. Effects of an 18-week exercise programme started early during breast cancer treatment: a randomised controlled trial. BMC Med 2015; 13: 121.

26. Biskup M, Król H, Opuchlik A, Macek P, Włoch A, Żak Ml. The role of physical activity in maintaining health after mastectomy. Medical Studies 2015; 31: 146-154.

27. Zak M, Biskup M, Macek P, Krol H, Krupnik S, Opuchlik A. Identifying predictive motor factors for falls in postmenopausal breast cancer survivors. PLoS One 2017; 12: e0173970.

\section{Address for correspondence:}

Marek Zak

Faculty of Medicine and Health Sciences

The Jan Kochanowski University

ul. IX Wiekow Kielc 19

25-317 Kielce, Poland

Phone: +48413496909

Email: mzak1@onet.eu 